\title{
Experimental evaluation of the effect of different design conditions on the risk of decay in solid wood exposed to outdoor climate
}

\author{
${ }^{\oplus}$ M. Conde-García ${ }^{a},{ }^{\oplus}$ M. Conde-García ${ }^{b},{ }^{\oplus J}$.A. Tenorio-Ríos ${ }^{c},{ }^{\oplus J}$. Fernández-Golfín ${ }^{\mathrm{a}} \bowtie$ \\ a. Forest Products Department, Wood Technology Lab. CIFOR-INIA, (Madrid) \\ b. Universidad de Córdoba, Escuela Técnica Superior de Ingenieros Agrónomos y Montes, (Córdoba) \\ c. Instituto de Ciencias de la Construcción Eduardo Torroja. CSIC, (Madrid) \\ golfin@inia.es
}

\begin{abstract}
Wood decay have the greatest impact on in-service wood structural elements. In most cases, decay is associated with excessive accumulation of moisture in the wood. The structural design conditions have an effect on the wood moisture content and this affects the service life of the material. In this study, which involved an experimental trial specifically designed to embrace different structural design conditions, the moisture content evolution in different places affected by different design conditions was evaluated over a period of three years in Madrid (Spain). The effect of protection by eaves, separation from the ground and the vertical or horizontal arrangement of the wood elements on the monthly evolution of the moisture content and decay risk are assessed.
\end{abstract}

KEYWORDS: Wood; Decay; Durability; Moisture content; Long-term behaviour.

Citation/Citar como: Conde-García, M.; Conde-García, M.; Tenorio-Ríos, J.A.; Fernández-Golfín, J. (2021) Experimental evaluation of the effect of different design conditions on the risk of decay in solid wood exposed to outdoor climate. Mater. Construcc. 71 [342], e247. https://doi.org/10.3989/mc.2021.12220.

RESUMEN: Evaluación experimental del efecto de diferentes condiciones de diseño en el riesgo de pudrición de la madera expuesta al clima exterior. La pudrición es el factor que mayor impacto tiene en la vida en servicio de los elementos estructurales de madera. En la mayoría de los casos, la pudrición se asocia con una acumulación excesiva de humedad en la madera. Las condiciones de diseño estructural tienen un efecto sobre el contenido de humedad y esto afecta la vida útil del material. Para realizar el estudio se hizo uso de un dispositivo experimental diseñado específicamente para incorporar diferentes condiciones de diseño estructural, evaluándose la evolución del contenido de humedad durante un período de tres años en Madrid (España) en diferentes posiciones afectadas por las condiciones de diseño. Se evalúa el efecto de la protección por aleros, la separación del suelo y la disposición vertical u horizontal de los elementos de madera sobre la evolución mensual del contenido de humedad y el riesgo de pudrición.

PALABRAS CLAVE: Madera; Pudrición; Durabilidad; Contenido de humedad; Comportamiento a largas edades.

Copyright: C2021 CSIC. This is an open-access article distributed under the terms of the Creative Commons Attribution 4.0 International (CC BY 4.0) License. 


\section{INTRODUCTION}

Predicting the performance of building products made from timber and other bio-based building materials has become increasingly important. Performance data are requested by designers, planners, authorities and approval bodies, but are rarely available (1).

Service life of timber structures in outdoor conditions is predominantly affected by the climatic conditions in terms of moisture and temperature over time (2). On-site wood decay is the result of a series of concomitant factors which make up the so-called "material climate" (the moisture content and temperature of the wood), which in turn has a direct impact on the service life of the wood products and constructions in which these products are employed (2).

Several previous studies have addressed the relationship between moisture content and fungal activity (cited in (3)), some of which have pointed to a risk of fungal attack even below the fibre saturation point, reaching the limit value of $16.3 \%$ in Picea abies (3). The risk of moisture leading to wood decay, however, is commonly considered to be above a moisture content of 20 to $30 \%$. Morris and Winandy (4) considered moisture content of between $20 \%$ and $30 \%$ to be a suspicious grey area and therefore, for safety reasons, proposed a limit value of $20 \%$ to be used in North American lightframed construction.

Isaksson and Thelandersson (5), who considered a moisture content threshold level of $25 \%$ to be that at which the decay process becomes active, proposed a measure of the moisture trapping effect of different features (including cracks) counting for the number of days in a year in which the moisture content is above $25 \%$. This indicator (number of days with a given $\mathrm{MC}$ value) was also considered by Meyer-Veltrup and Brischke (6) as a useful and simple alternative indicator to the more complex and accurate performance models (7).

Different works at European level $(5,8$-10) have proposed new technical guidelines for the design of buildings constructed using timber with respect to durability and service life, based on a parametric system similar to that used in mechanical engineering. These guidelines are based on a limit state described as "onset of decay", defined as a state of fungal attack according to rating 1 in EN 252 (11).

As stated above, in analogy to mechanical engineering, the design principle used in these technical guides is based on the use of expression (Equation [1]) to evaluate every aspect of the design:

$$
\text { Exposure } \leq \text { Resistance }
$$

In expression [1] the exposure is calculated taking into account the basic exposure doses at each site according to the daily averages for material climate, modified in accordance with all the factors influencing this material climate (local exposure conditions, sheltering, distance to ground, design of details and other concomitant factors). Similarly, the design-material resistance is calculated considering a critical dose against biological agents modified by all the factors that affect this basic resistance (wetting and drying ability and crack susceptibility of the species used, protection systems, stability, etc.).

This approach, considering a basic value, not only for exposure but also for resistance, modified by all the factors affecting the basic values, closely follows the factor method idea according to ISO 15686-1 (12) and is an engineering approach for evaluating each decision regarding design and species/protection.

According to Marteinsson (13), the first to propose the use of the factor method to evaluate wood durability, when applied to wood the "factor method" consists of determining a reference value for durability, hazard or "service life", which must then be corrected by applying a series of factors which take into account different concomitant aspects related to both the material itself (species, dimensions, treatments applied, type of material etc.) as well as the "climate" in which the material is employed, or other aspects such as design details or hazards associated with the failure of the element in question (14).

In expression [1] and according to the above-cited technical European guidelines $(5,8-10)$ the calculation of the characteristic exposure value $\left(I_{S k}\right)$, left part of the inequality, for a specific design detail should be done by means of the following expression (Equation [2]):

$$
I_{S k}=I_{S 0} * k_{s 1} * k_{s 2} * k_{s 3} * k_{s 4} \ldots * k_{s i}
$$

In expression (Equation [2]) $I_{s 0}$ represents the basic exposure index which is defined for every site based on the material climate of a horizontal wooden element exposed to outdoor conditions in terms of precipitation, relative humidity and temperature. To not increment artificially the exposure, the element used for defining the basic exposure index of the sites $I_{s 0}$ must avoid any moisture traps. Due to its common use in construction all over Europe, the experimental value of the basic exposure index $I_{s 0}$ is based on the use of Norway spruce (Picea abies) as reference material.

Most design situations mean higher risk for moisture trapping than in the reference material configuration and, consequently, longer periods of higher moisture content in the material with increased risk for onset of decay (7). These situations and other local conditions are accounted for in expression (Equation [2]) by using different factors $\left(k_{s i}\right)$, that should be obtain in empirical studies. 
Different studies have also been conducted $(5$, $6,15-21)$ to improve the knowledge about the degradation processes in different constructive solutions as to façades and deckings but most of these studies have been undertaken in northern European climates where the effect of cracks due to complete drying of the wood in the summer months is much lower than in European countries with a Mediterranean climate. The majority of these studies are not oriented to propose $k_{s i}$ values to be used in the expression (Equation [2]).

As regards the calculation of the basic exposure index $\left(I_{s 0}\right)$ for all the Spanish territory, and knowing its international recognition (21-24), Fernández-Golfín et al. (14) worked with the historic (1981-2010) grids of precipitation and temperature with a resolution of $1 \mathrm{~km}$ by $1 \mathrm{~km}$, developed by the Spanish Meteorological Agency (AEMET), calculating not only the Scheffer decay index (25) but also a modified Scheffer index taking into consideration the effect of condensations.

Afterwards, Fernández-Golfín et al. (23) made use of the Spanish values of the Scheffer decay index to determine the basic index of exposure $\left(I_{s 0}\right)$ applicable to wood in outdoor conditions above ground all over Spain by means of a scoring system. Similarly and following a parametric system based on the analysis and evaluation of the climatic conditions of the material in each condition of use and place, this characterization of the basic index of exposure was also extended to the remaining conditions of use of wood in buildings: inside a construction and under cover and not exposed to the weather.

This work of characterization of the basic index of exposure in all possible conditions of use of timber in buildings, together with the use of the $k_{s i}$ factors proposed in (8-10), led to the development in Spain of a system of assignment of classes of use of the standard EN $335(26,27)$ which, complemented with an EXCEL application, has been successfully tested in hundreds of building works. The use of the expression (Equation [2]) as guidance on the application of the EN 335 use classes to solid wood is a national interim solution to overcome the already deficient degree of development of the European standardization process regarding the application of the engineering approach to evaluate the effect of every design and species/protection decision on the service life or durability.

With the spirit of increasing the knowledge and quantification on the factors affecting the basic index of exposure $k_{s i}$ of the expression (Equation [2]) and verify the values proposed by the existing European technical guides (8-10), in the context of the Spanish national project BIA-42434R on the Evaluation of functional behaviour of wood in outdoor above ground applications, work is being done on the evaluation and quantification of the effect of the factors most commonly involved in structural design as well as the influence of the species factor on the risk of decay.

As far as the calculation of characteristic value of resistance $\left(D_{R D}\right)$, right part of the inequality in expression (Equation [1]), is concerned this should be done by means of the following expression (Equation [3]):

$$
D_{R D}=D_{c r i t} * k_{w a} * k_{i n h} * \ldots * k_{s i}
$$

In the expression (Equation [3]) $D_{\text {crit }}$ is the critical dose corresponding to decay rating 1 according to EN 252 (11), $k_{w a}$ a factor accounting for the effect of species, $k_{i n h}$ a factor accounting for the inherent protective properties of the tested materials against decay and $k_{s i}$ different factors accounting for any other material properties affecting the material climate. All this factors $\left(D_{c r i t}, k_{w a}, k_{i n h}, k_{s i}\right)$ must be relative to the behavior of the reference material: untreated Norway spruce.

Currently there is a draft standard, the PNE-prEN 460: 2020 (28), that is concerned with performance classification for wood and wood-based products, being this a basic aspect for the above-cited engineering approach to the durability of materials and constructive solutions. In its current wording the standard itself refers to its limitations and the need for reliable methods to prevent misleading interpretation of durability data and to avoid unjustified expectations of service life. The early concepts and objectives of this standard can be read in (29) and a revision on European standards on durability and performance of wood and wood-based products can be read in (30).

Whereas a previous study of this research team was focused on the effect of climatic conditions on expected service life in Spain $(14,26)$, this study aims to improve our understanding of the effect of three design variables (protection by eaves, separation from the ground and vertical/horizontal arrangement) on the evolution throughout the year of the moisture content of the wooden elements and thus on the increase or decrease in the basic risk of decay.

It should be stated that both the present study and the majority of those cited in the bibliography deal with the basic risk of degradation associated with wood-rot fungi, since insect attack (except by termites) is not dependent on the moisture content of the wood and must be addressed using a multidisciplinary approach considering barrier-type protection.

\section{MATERIALS AND METHODS}

To assess and predict the long-term moisture performance of wooden elements affected by different 
design factors, an experimental set-up was erected in Madrid in March 2016. The experimental device (Figure 1) consisted of two untreated Scots pine ( $P i$ nus sylvestris L., Valsain provenance) wood pillars with a cross section of $90 \times 70 \mathrm{~mm}^{2}$ and a total length of $2250 \mathrm{~mm}$. The two pillars were placed $1580 \mathrm{~mm}$ apart from each other and joined by an upper horizontal piece of the same dimensions. This horizontal piece was also made of untreated Scots pine wood. The horizontal beam overhanged the pillars $300 \mathrm{~mm}$ at each end. The pillars were inserted directly into the ground to a depth of $500 \mathrm{~mm}$.

In order to provide rigidity to the structure and to assess the effect of the joints (assessment not included in the present study), two untreated Scots pine wood struts of $90 \times 70 \times 500 \mathrm{~mm}^{3}$ were placed at a $45^{\circ}$ angle, joining the beam to the pillars.

To minimise the effect of the geographical orientation, the horizontal beam was placed in a NorthSouth direction. The orientation effect was avoided in the present study by inserting all the moisture sensors on the East face of the monitored wood elements, except for sensor 1 that was placed on the south face.

Finally, in order to assess the eaves effect on the evolution of moisture content, a plywood board measuring $600 \times 600 \mathrm{~mm}^{2}$ was placed at the southern end of the horizontal beam, flush with the its end and extending $255 \mathrm{~mm}$ on each side, thus partially protecting the South, East and West sides of the southern pillar (eave factor).

The moisture content was measured continuously by electrical resistance method according to EN 13183-2:2002 at representative locations, selected in order to capture the effects of both the protective measures undertaken and the moisture traps involved. The location of each moisture sensor was selected according with the effect to evaluate. Moisture sensors are shown in Figure 1, the functions of each being the following:

- Sensor 1 (Southern pillar, immediately under the overhanged part of the beam to avoid any risk of condensation effect from the plywood board used as eaves. The orientation has no effect in this position since neither the sun nor the rain affects the area): To evaluate the effect of the eaves through comparison with the measurements from sensor 2 .

- Sensor 2 (Southern pillar, $700 \mathrm{~mm}$ from the upper edge, facing east): To evaluate the moisture content in vertically placed elements beyond the effect of the eaves. The selected position of measurement point 2 with respect to the plywood board $(700 \mathrm{~mm})$ was determined by manual measurements taken after rain events throughout 2016 in both pillars, looking for the place from which the moisture content becomes substantially constant (eaves effect completion). This made it possible to use the difference in moisture content measurements taken at points 1 and 2 as an indicator of the eaves effect. Due to the importance of the measure in sensor 2 (is the base of the assessment of all the factors considered in the present study), the exactitude of the automatically monitored measure was checked monthly (outside of rain events) comparing it with the measurement taken manually at point T (GANN RTU 600) on the northern pillar (Figure 1). The checking was done with measures taken at 12:00 a.m.

- Sensor 3 (Southern pillar, $200 \mathrm{~mm}$ from the ground, facing east): To evaluate the effect of proximity to the ground through comparison with the measurements from sensor 2 . This $200 \mathrm{~mm}$ separation from the ground was selected being the one considered safe in the DBE-SEM rules of the Spanish Code of Practice (31). It was not considered to use nor barriers nor systems preventing the capillary ascent of the water through the pillars to reproduce many of the real situations that occur in construction practice and to simulate and assess the effect of timber embedding in damp walls (beams).

- Sensor 4 (Horizontal element, facing east): To evaluate the effect of position (vertical vs. horizontal) through comparison with the measurements at point 2 .

To monitor the moisture content in each of the selected point of the experimental set-up and thereby evaluate the effect of the different design variables, a couple of Gann 31004550 steel Teflon covered electrodes were inserted, in the longitudinal direction with respect to the fibres, to a depth of $20 \mathrm{~mm}$. The distance between the two electrodes of each sensor was $25 \mathrm{~mm}$.

The moisture content of each measuring point were recorded every two hours using a data logging device installed inside a protective box to prevent leaking. The device used to measure and record the moisture content of the wood was composed of an eight channel moisture sensor (Type Gigamodule, Scanntronik $\mathrm{GmbH}$ ) and a datalogger (Type Thermofox, Scanntronik GmbH), which have commonly been employed in other similar studies conducted at European level.

To determine the temperature of the wood a RTD type temperature sensor was inserted into the Southern pillar (next to measuring point number 2 in Figure 1), recording the temperature at the same time than the moisture content.

To obtain high quality data and to avoid measurement errors, the functioning of the measurement device (Gigamodule) was continuously monitored by connecting a 10 Mohms calibrated resistance to channel 8 as well as carrying out monthly controls using manual devices (GANN RTU600) for 


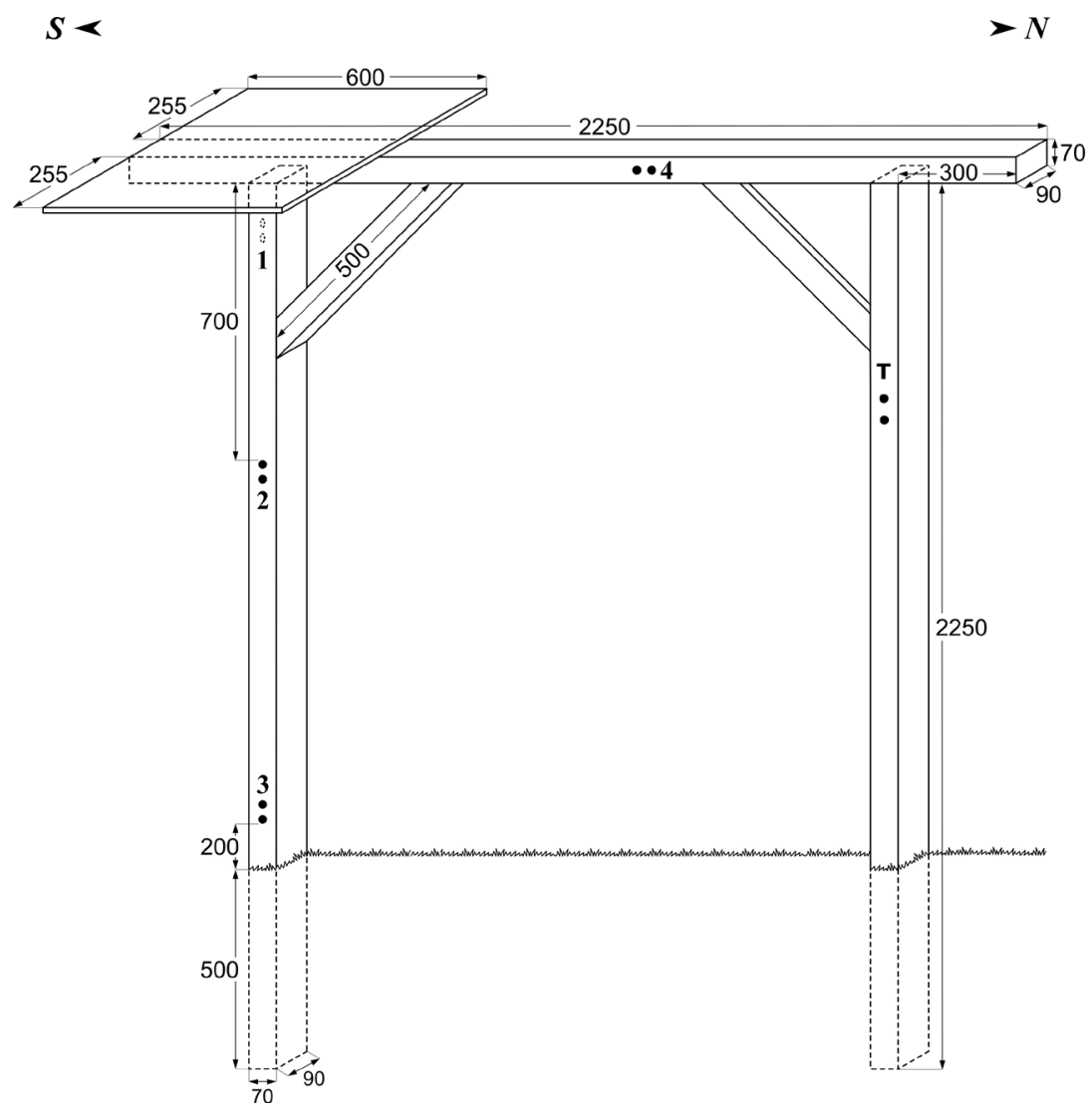

FiguRE 1. General view of experimental set-up (all dimensions in mm).

measuring the moisture content of each measuring point using moisture content sensors similar to those used for the primary measurements. Thus, a monthly comparison between primary and secondary measurements was performed, taking into account the acceptance criteria of maximum differences of $\pm 2 \%$. All the manual measurements were taken in the absence of active rain events. Fortunately, all the measurements were within the acceptance threshold.

All the moisture content measurements recorded by the Gigamodule were corrected for a temperature of $20^{\circ} \mathrm{C}$. To take into consideration the species effect on moisture content measurements a specifically developed for Scots pine in the INIA laboratories (32) was used.

To assign each construction detail to a use class of the EN 335 standard (27), the following two steps methodology was used:

1. Calculation of the zonal basic exposure index value by means of the monthly average value of the moisture content and the allocation criterion considered in Table 1 (scoring system only applicable to solid wood).

2. Assignment of the class of use based on the value of the basic exposure index (see first step) and the criteria contemplated in Table 2.
The index values according to moisture content (MC) intervals reported in Table 1 and the criteria for assignment to classes of use considered in Table 2 come from the experience and previous work of this research team and have been successfully used for the assignment of classes of use in many real situations by means of an EXCEL tool specifically built for this objective (26).

\section{RESULTS AND DISCUSSION}

Table 3 presents a summary of the average MC monthly values obtained from each sensor, indicating the maximum and minimum values. The table 3 also includes the values for average monthly air temperature $\left(\mathrm{T}_{\mathrm{AV}}\right)$, total monthly precipitation $\left(\mathrm{P}_{\mathrm{t}}\right)$, total number of days with over $0.2 \mathrm{~mm}$ of rainfall $(\mathrm{Nt})$, days with more than $0.2 \mathrm{~mm}$ but less than $1 \mathrm{~mm}$ of rainfall $\left(\mathrm{N}_{02}\right)$, more than $1 \mathrm{~mm}$ but less than $5 \mathrm{~mm}\left(\mathrm{~N}_{10}\right)$ or more than $5 \mathrm{~mm}\left(\mathrm{~N}_{50}\right)$. Average values for relative air humidity $(\mathrm{RH})$, along with average monthly values calculated for equilibrium moisture content (EMC) are also included. All the climatological values included correspond to those published by the Spanish Meteorological Agency (AEMET) from the meteorological station of the Ciudad Universitaria, located at $1 \mathrm{~km}$ from the site of the experiment. 
TABLE 1. Index value assignment according to moisture content (MC).

\begin{tabular}{ccl}
\hline MC Interval (\%) & Index value & \multicolumn{1}{c}{ Comments } \\
\hline$\geq 25$ & 4.0 & Fast development of fungi. Extreme risk of decay \\
\hline$\geq 22-25$ & 3.5 & Threshold for high risk of fungi and termite attacks \\
\hline $20-22$ & 3.2 & Moderate risk of fungi and termite attacks \\
\hline$\geq 18-20$ & 3.0 & Start of risk of fungi and termite attacks. 18\% is the upper threshold for Service Class 2 (solid wood) \\
\hline$\geq 16-18$ & 2.7 & Reduced risk of fungal attack \\
\hline$\geq 14-16$ & 2.5 & No risk of fungi and termite attacks \\
\hline$\geq 12-14$ & 2.0 & No risk of fungi and termite attacks .12\% is the upper limit for Service Class 1 (solid wood) \\
\hline$\geq 10-12$ & 1.0 & No risk of fungi and termite attacks \\
\hline$\geq 9-10$ & 0.9 & No risk of fungi and termite attacks \\
\hline$\geq 8-9$ & 0.8 & No risk of fungi and termite attacks \\
\hline$<8$ & 0.7 & Moisture content incompatible with fungi survival \\
\hline
\end{tabular}

TABLE 2. Assignment of use class (UC) based on the humidity factor.

\begin{tabular}{ccl}
\hline Index value & Assignation & \multicolumn{1}{c}{ Comments } \\
\hline $0-0.7$ & $\mathrm{UC} 1$ & Inside constructions. No rain. No condensation \\
\hline$>0.7-1.3$ & $\mathrm{UC2}$ & Only under cover. No rain. No frequent condensation \\
\hline$>1.3-1.7$ & $\mathrm{UC3} .1$ & Exposed \\
\hline$>1.7$ & $\mathrm{UC3} .2$ & Exposed \\
\hline
\end{tabular}

Part of the information of Table 3 can be seen graphically in Figure 2(a) and Figure 2(b), describing the evolution over time of the MC4AV, $\mathrm{N}_{t}, \mathrm{~N}_{50}$ and $\mathrm{P}_{\mathrm{t}}$ variables. The first aspect to highlight is that total precipitation $\left(\mathrm{P}_{\mathrm{t}}\right)$ is the factor neither that most affects it nor the one that is best related to the moisture content (reflected in this case by the value of MC4AV, the one of the horizontal member). As can be seen graphically, the monthly evolution of the variables $\mathrm{N}_{t}$ and $\mathrm{N}_{50}$ are more closely related than $\mathrm{P}_{t}$ with the monthly evolution of moisture content (MC4AV).

Table 4 shows a summary of the calculated monthly values for the number of days with a moisture content above $18 \%(\mathrm{~N} 18)$, above $22 \%$ (N22) or above $25 \%$ (N25) for each of the measurement sensors. The number of days with moisture content greater than a given value is an easy and useful indicator of the decay potential and how the different positions within a structure are affected by the climatological or design variables. There is some discussion about the best threshold to be used as indicator of decay risk. For this reason in this work we have presented the three more common $(18 \%, 22 \%, 25 \%)$, even though we usually make use of $18 \%$ (33).

Figure 3 provides a graphical representation of the monthly average values of N18, N22 and N25 registered by sensors 1 to 4 over the three years of the study. The area contained within the polygonal line obtained by joining all the points corresponding to the same risk level (N18, N22, N25) is an indicator of the potential risk of decay.

The protective effect of the eaves is very evident (MC1, Figure 3a), since there is no risk indicator surface at any level. The decay risk associated with a fully exposed vertical position but out of contact with the ground (MC2, Figure 3b) is very limited and is only slightly evident considering a risk MC threshold of $22 \%$ (N22).

The decay risk for the fully exposed vertical exposition close to the ground $(200 \mathrm{~mm})$ but not in direct contact with it (MC3, Figure 3c) is moderate, being much more evident considering the risk MC threshold of $22 \%$ (N22). Finally and for the horizontal element (MC4, Figure 3d) the decay risk is higher, especially considering a risk MC threshold of $18 \%$ but being also evident with the thresholds of $22 \%(\mathrm{~N} 22)$ and $25 \%$ (N25).

In any of the four expositions considered, the enormous influence that summer has on the material climatic conditions in Madrid is evident, under which the wooden elements dry out completely and the decay risk is reduced to zero.

Table 5 includes a summary of the monthly values for the differences among the sensor measurements, which can be used to evaluate the effect of: 
TABLE 3. Summary of monthly average, maximum and minimum values of Moisture Content (MC) per sensor, average Equilibrium Moisture Content (EMC) and climatological values.

\begin{tabular}{|c|c|c|c|c|c|c|c|c|c|c|c|c|c|c|c|c|c|c|c|c|}
\hline $\begin{array}{l}\overline{\underline{E}} \\
\stackrel{\Xi}{\Sigma}\end{array}$ & 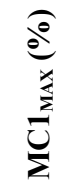 & 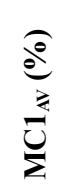 & $\frac{\underbrace{o}_{z}}{\frac{\partial}{2}}$ & 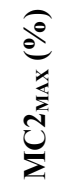 & 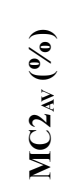 & 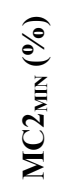 & 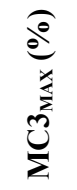 & 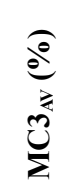 & 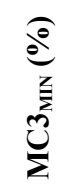 & 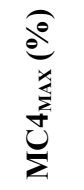 & $\begin{array}{l}\underbrace{o} \\
\frac{\partial}{z} \\
\frac{e^{2}}{z}\end{array}$ & 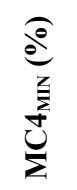 & $\underbrace{0}_{\hat{R}}$ & $\underset{\mathrm{a}^{-}}{\widehat{\Xi}}$ & 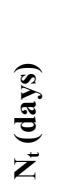 & 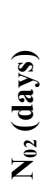 & 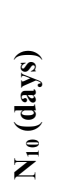 & 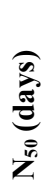 & 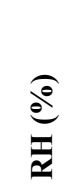 & 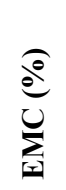 \\
\hline$n-17$ & 15.0 & 14.4 & 14.3 & 19.1 & 16.3 & 15.8 & 21.2 & 17.1 & 16.5 & 27.8 & 21.3 & 20.4 & 5.1 & 20.4 & 3 & 1 & 1 & 1 & 63.0 & 12.1 \\
\hline feb-17 & 15.3 & 14.9 & 14.3 & 17.7 & 17.3 & 16.1 & 19.1 & 18.7 & 17.3 & 29.2 & 23.9 & 21.0 & 7.4 & 51.0 & 11 & $J$ & 4 & 4 & 65.0 & 12.5 \\
\hline mar-17 & 14.6 & 13.4 & 12.3 & 16.0 & 14.7 & 13.7 & 16.8 & 15.7 & 14.8 & 25.5 & 20.3 & 17.3 & 10.5 & 16.7 & 7 & 1 & 6 & 0 & 53.0 & 10.1 \\
\hline apr-17 & 12.5 & 11.1 & 10.2 & 14.0 & 12.2 & 11.0 & 15.2 & 13.6 & 12.7 & 19.5 & 16.4 & 14.4 & 14.7 & 13.2 & 7 & 2 & 5 & 0 & 41.0 & 7.9 \\
\hline may-17 & 10.7 & 9.9 & 9.0 & 11.6 & 10.8 & 9.8 & 14.0 & 12.4 & 11.5 & 19.0 & 14.9 & 12.3 & 19.1 & 29.9 & 5 & 1 & 2 & 2 & 39.0 & 7.5 \\
\hline jun-17 & 8.9 & 7.9 & 7.6 & 9.7 & 8.7 & 8.2 & 11.3 & 10.6 & 10.3 & 13.1 & 12.2 & 10.8 & 25.6 & 11.2 & 5 & 4 & 0 & 1 & 34.0 & 6.5 \\
\hline jul-17 & 10.7 & 7.7 & 6.6 & 11.5 & 8.5 & 7.0 & 14.0 & 10.7 & 9.8 & 19.0 & 11.1 & 8.8 & 25.8 & 61.1 & 4 & 1 & 1 & 2 & 34.0 & 6.5 \\
\hline aug-17 & 7.7 & 6.7 & 6.3 & 12.1 & 7.6 & 7.1 & 15.7 & 10.0 & 9.4 & 18.9 & 9.0 & 7.6 & 26.1 & 22.7 & 3 & 2 & 0 & 1 & 38.0 & 7.1 \\
\hline sep-17 & 7.8 & 7.0 & 6.9 & 8.0 & 7.8 & 7.6 & 10.4 & 9.9 & 9.7 & 10.0 & 8.8 & 8.6 & 20.8 & 0.0 & 0 & 0 & 0 & 0 & 39.0 & 7.4 \\
\hline-17 & 10.0 & 7.8 & 6.9 & 16.5 & 10.4 & 8.0 & 20.0 & 12.9 & 9.8 & 24.8 & 13.4 & 8.6 & 17.6 & 28.8 & 3 & 2 & 0 & 1 & 47.0 & 8.8 \\
\hline nov-17 & 10.9 & 9.7 & 8.7 & 14.7 & 11.2 & 10.4 & 18.0 & 13.0 & 11.7 & 23.8 & 14.9 & 12.5 & 9.4 & 8.9 & 4 & 2 & 1 & 1 & 53.0 & 10.1 \\
\hline dec-17 & 11.9 & 11.1 & 10.7 & 18.0 & 13.6 & 11.7 & 23.4 & 16.4 & 12.6 & 28.0 & 18.3 & 12.5 & 6.1 & 19.9 & 6 & 3 & 2 & 1 & 59.0 & 11.3 \\
\hline jan-18 & 15.7 & 13.2 & 11.8 & 19.5 & 15.5 & 13.0 & 26.0 & 19.8 & 14.8 & 31.4 & 22.9 & 17.9 & 6.6 & 50.2 & 9 & 3 & 2 & 4 & 68.0 & 13.2 \\
\hline b-18 & 15.9 & 13.5 & 12.5 & 19.0 & 16.3 & 13.8 & 26.9 & 22.2 & 17.2 & 29.8 & 24.6 & 19.2 & 5.5 & 67.2 & 5 & 0 & 1 & 4 & 54.0 & 10.4 \\
\hline mar-18 & 15.7 & 14.0 & 11.3 & 23.0 & 20.5 & 15.6 & 29.5 & 25.2 & 18.0 & 33.0 & 27.3 & 18.6 & 8.6 & 148.3 & 19 & 1 & 9 & 9 & 59.0 & 11.3 \\
\hline$r-18$ & 11.8 & 11.0 & 10.1 & 19.6 & 15.9 & 10.5 & 25.0 & 18.8 & 11.5 & 32.0 & 23.0 & 15.7 & 12.5 & 56.5 & 14 & 3 & 7 & 4 & 54.0 & 10.2 \\
\hline may-18 & 11.8 & 9.6 & 7.6 & 17.2 & 10.9 & 8.2 & 20.5 & 12.1 & 8.9 & 26.7 & 13.2 & 9.0 & 16.5 & 51.6 & 14 & 7 & 5 & 2 & 46.0 & 8.7 \\
\hline jun-18 & 11.8 & 9.6 & 7.6 & 17.2 & 10.9 & 8.2 & 20.5 & 12.1 & 8.9 & 26.7 & 13.2 & 9.0 & 21.9 & 34.1 & 3 & 0 & 1 & 2 & 43.0 & 8.0 \\
\hline jul-18 & 7.4 & 6.7 & 6.3 & 8.1 & 7.5 & 7.2 & 10.4 & 9.5 & 8.6 & 9.8 & 8.7 & 8.1 & 25.5 & 0.0 & 0 & 0 & 0 & 0 & 36.0 & 6.8 \\
\hline aug-18 & 7.1 & 6.6 & 6.3 & 7.4 & 7.1 & 6.9 & 9.4 & 9.2 & 8.8 & 8.8 & 7.8 & 7.4 & 27.5 & 0.6 & 1 & 1 & 0 & 0 & 38.0 & 7.0 \\
\hline sep-18 & 7.8 & 7.1 & 6.5 & 8.6 & 7.3 & 7.0 & 10.7 & 9.0 & 8.2 & 14.5 & 8.6 & 7.5 & 23.9 & 2.4 & 3 & 2 & 1 & 0 & 45.0 & 8.3 \\
\hline 10 & 10.5 & 9.3 & 7.1 & 13.0 & 10.8 & 7.4 & 16.5 & .3 & 9.1 & .4 & 17.3 & 8.0 & 15.0 & 42.2 & 14 & 2 & 10 & 2 & 55.0 & 10.3 \\
\hline nov-18 & 12.4 & 11.5 & 10.4 & 18.0 & 15.4 & 11.1 & 23.7 & 19.3 & 14.0 & 27.1 & 22.8 & 17.2 & 10.1 & 59.7 & 17 & 6 & 7 & 4 & 67.0 & 12.9 \\
\hline $\mathbf{0}$ & 12.3 & 12.1 & 12.0 & 19.0 & 14.7 & 14.0 & 22.2 & 18.3 & 16.5 & 27.0 & 21.0 & 19.5 & 7.2 & 9.5 & 4 & 3 & 0 & 1 & 66.0 & 12.7 \\
\hline jan-19 & 13.3 & 12.7 & 12.3 & 18.3 & 15.2 & 14.0 & 22.0 & 17.6 & 16.0 & 27.4 & 19.6 & 16.7 & 6.0 & 9.8 & 3 & 1 & 1 & 1 & 56.0 & 10.8 \\
\hline feb-19 & 13.2 & 12.3 & 11.4 & 17.7 & 13.4 & 11.7 & 22.5 & 16.4 & 14.9 & 26.9 & 18.7 & 16.1 & 2 & 0.5 & 1 & 1 & 0 & 0 & 50.0 & .0 \\
\hline mar-19 & 11.8 & 10.7 & 9.6 & 15.3 & 11.9 & 10.5 & 21.3 & 15.1 & 13.3 & 26.1 & 16.8 & 13.8 & 11.4 & 7.7 & 2 & 1 & 0 & 1 & 45.0 & 8.7 \\
\hline-19 & 11.3 & 10.9 & 10.3 & 16.9 & 14.8 & 12.5 & 23.2 & 19.3 & 14.5 & .4 & 22.9 & .3 & 12.2 & 70.1 & 12 & 3 & J & 4 & 51.0 & 9.7 \\
\hline may-19 & 10.2 & 8.9 & 7.8 & 12.2 & 9.9 & 8.6 & 15.6 & 12.2 & 10.5 & 17.1 & 12.0 & 10.5 & 18.7 & 1.5 & 1 & 0 & 1 & 0 & 41.0 & 7.8 \\
\hline jun-19 & 8.1 & 7.3 & 6.9 & 11.6 & 8.4 & 7.6 & 15.2 & 10.5 & 9.6 & 16.7 & 9.7 & 8.2 & 23.7 & 1.2 & 1 & 0 & 1 & 0 & 36.0 & 6.9 \\
\hline jul-19 & 7.3 & 7.0 & 6.9 & 10.5 & 8.3 & 7.6 & 14.6 & 10.7 & 9.4 & 16.4 & 10.5 & 7.3 & 27.3 & 3.4 & 5 & 4 & 1 & 0 & 34.0 & 6.4 \\
\hline aug-19 & 7.1 & 6.5 & 6.3 & 11.2 & 7.5 & 6.7 & 14.6 & 9.7 & 8.2 & 17.3 & 10.8 & 8.4 & 25.3 & 82.3 & 5 & 2 & 1 & 2 & 39.0 & 7.3 \\
\hline sep-19 & 7.5 & 6.8 & 6.6 & 11.7 & 8.7 & 7.5 & 15.6 & 10.9 & 9.3 & 19.4 & 12.7 & 9.1 & 20.6 & 28.3 & 5 & 1 & 2 & 2 & 45.0 & 8.4 \\
\hline oct-19 & 9.0 & 7.8 & 6.9 & 14.8 & 10.4 & 7.7 & 19.6 & 12.9 & 9.1 & 25.1 & 15.4 & 9.3 & 15.6 & 37.4 & 9 & 2 & 4 & 3 & 54.0 & 10.1 \\
\hline nov-19 & 11.7 & 10.3 & 8.9 & 17.7 & 14.1 & 10.7 & 23.2 & 17.3 & 12.5 & 26.2 & 20.1 & 14.2 & 9.4 & 38.2 & 13 & 2 & 8 & 3 & 63.0 & 12.0 \\
\hline dec-19 & 13.0 & 12.5 & 11.9 & 22.1 & 17.0 & 14.6 & 28.7 & 20.4 & 16.2 & 30.8 & 22.7 & 17.5 & 8.4 & 85.0 & 12 & 4 & 5 & 3 & 64.0 & 12.3 \\
\hline
\end{tabular}


TABLE 4. Summary of monthly values of number of days with Moisture content above $12 \%$ (N12), 18\% (N18), 22\% (N22) or 25\% (N25) per sensor (MCX).

\begin{tabular}{|c|c|c|c|c|c|c|c|c|c|c|c|c|c|c|c|c|}
\hline 吾 & 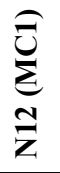 & 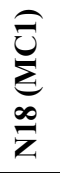 & $\begin{array}{l}\underset{\tilde{U}}{\tilde{Z}} \\
\underset{\mathrm{z}}{\mathrm{Z}}\end{array}$ & $\underset{\substack{\tilde{J} \\
\tilde{z}}}{\stackrel{u}{z}}$ & 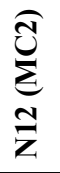 & 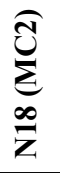 & $\begin{array}{l}\underset{\mathbb{Z}}{\tilde{Z}} \\
\underset{Z}{Z}\end{array}$ & $\underset{\substack{\tilde{Z} \\
\tilde{z}}}{\underset{Z}{\tilde{Z}}}$ & 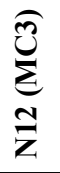 & $\sum_{\substack{\infty \\
Z}}^{\tilde{Z}}$ & $\begin{array}{l}\underset{\tilde{Z}}{\tilde{Z}} \\
\underset{\tilde{Z}}{2}\end{array}$ & $\underset{\substack{\tilde{Z} \\
\tilde{z}}}{\stackrel{0}{n}}$ & 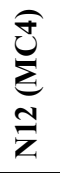 & 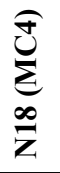 & $\begin{array}{l}\underset{\mathbb{J}}{J} \\
\underset{Z}{Z}\end{array}$ & 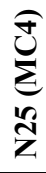 \\
\hline jan-17 & 31 & 0 & 0 & 0 & 31 & 5 & 0 & 0 & 31 & 5 & 0 & 0 & 31 & 31 & 6 & 4 \\
\hline feb-17 & 28 & 0 & 0 & 0 & 28 & 0 & 0 & 0 & 28 & 27 & 0 & 0 & 28 & 28 & 23 & 9 \\
\hline mar-17 & 31 & 0 & 0 & 0 & 31 & 0 & 0 & 0 & 31 & 0 & 0 & 0 & 31 & 29 & 7 & 1 \\
\hline apr-17 & 5 & 0 & 0 & 0 & 14 & 0 & 0 & 0 & 30 & 0 & 0 & 0 & 30 & 6 & 0 & 0 \\
\hline may-17 & 0 & 0 & 0 & 0 & 0 & 0 & 0 & 0 & 22 & 0 & 0 & 0 & 31 & 3 & 0 & 0 \\
\hline jun-17 & 0 & 0 & 0 & 0 & 0 & 0 & 0 & 0 & 0 & 0 & 0 & 0 & 27 & 0 & 0 & 0 \\
\hline jul-17 & 0 & 0 & 0 & 0 & 0 & 0 & 0 & 0 & 4 & 0 & 0 & 0 & 6 & 3 & 0 & 0 \\
\hline aug-17 & 0 & 0 & 0 & 0 & 1 & 0 & 0 & 0 & 2 & 0 & 0 & 0 & 3 & 1 & 0 & 0 \\
\hline sep-17 & 0 & 0 & 0 & 0 & 0 & 0 & 0 & 0 & 0 & 0 & 0 & 0 & 0 & 0 & 0 & 0 \\
\hline oct-17 & 0 & 0 & 0 & 0 & 11 & 0 & 0 & 0 & 15 & 3 & 0 & 0 & 15 & 7 & 3 & 0 \\
\hline nov-17 & 0 & 0 & 0 & 0 & 7 & 0 & 0 & 0 & 17 & 1 & 0 & 0 & 30 & 5 & 2 & 0 \\
\hline dec-17 & 0 & 0 & 0 & 0 & 25 & 1 & 0 & 0 & 31 & 10 & 3 & 0 & 31 & 12 & 6 & 3 \\
\hline jan-18 & 27 & 0 & 0 & 0 & 31 & 6 & 0 & 0 & 31 & 22 & 8 & 5 & 31 & 30 & 15 & 9 \\
\hline feb-18 & 28 & 0 & 0 & 0 & 28 & 3 & 0 & 0 & 28 & 25 & 7 & 3 & 28 & 28 & 12 & 5 \\
\hline mar-18 & 27 & 0 & 0 & 0 & 31 & 28 & 10 & 0 & 31 & 31 & 24 & 20 & 31 & 31 & 27 & 24 \\
\hline apr-18 & 0 & 0 & 0 & 0 & 26 & 8 & 0 & 0 & 28 & 19 & 7 & 1 & 30 & 22 & 18 & 13 \\
\hline may-18 & 0 & 0 & 0 & 0 & 23 & 2 & 0 & 0 & 31 & 9 & 3 & 0 & 31 & 19 & 5 & 4 \\
\hline jun-18 & 0 & 0 & 0 & 0 & 11 & 0 & 0 & 0 & 12 & 3 & 0 & 0 & 14 & 4 & 2 & 1 \\
\hline jul-18 & 0 & 0 & 0 & 0 & 0 & 0 & 0 & 0 & 0 & 0 & 0 & 0 & 0 & 0 & 0 & 0 \\
\hline aug-18 & 0 & 0 & 0 & 0 & 0 & 0 & 0 & 0 & 0 & 0 & 0 & 0 & 0 & 0 & 0 & 0 \\
\hline sep-18 & 0 & 0 & 0 & 0 & 0 & 0 & 0 & 0 & 0 & 0 & 0 & 0 & 1 & 0 & 0 & 0 \\
\hline oct-18 & 0 & 0 & 0 & 0 & 15 & 0 & 0 & 0 & 22 & 0 & 0 & 0 & 23 & 18 & 11 & 0 \\
\hline nov-18 & 7 & 0 & 0 & 0 & 27 & 1 & 0 & 0 & 30 & 23 & 5 & 0 & 30 & 29 & 16 & 8 \\
\hline dec-18 & 31 & 0 & 0 & 0 & 31 & 1 & 0 & 0 & 31 & 16 & 2 & 0 & 31 & 31 & 6 & 1 \\
\hline jan-19 & 31 & 0 & 0 & 0 & 31 & 4 & 0 & 0 & 31 & 11 & 1 & 0 & 31 & 19 & 7 & 4 \\
\hline feb-19 & 20 & 0 & 0 & 0 & 23 & 0 & 0 & 0 & 28 & 5 & 1 & 0 & 28 & 13 & 4 & 1 \\
\hline mar-19 & 0 & 0 & 0 & 0 & 10 & 0 & 0 & 0 & 31 & 4 & 0 & 0 & 31 & 8 & 4 & 1 \\
\hline apr-19 & 0 & 0 & 0 & 0 & 30 & 0 & 0 & 0 & 30 & 20 & 5 & 0 & 30 & 26 & 19 & 13 \\
\hline may-19 & 0 & 0 & 0 & 0 & 2 & 0 & 0 & 0 & 16 & 0 & 0 & 0 & 12 & 0 & 0 & 0 \\
\hline jun-19 & 0 & 0 & 0 & 0 & 0 & 0 & 0 & 0 & 3 & 0 & 0 & 0 & 3 & 0 & 0 & 0 \\
\hline jul-19 & 0 & 0 & 0 & 0 & 0 & 0 & 0 & 0 & 7 & 0 & 0 & 0 & 8 & 0 & 0 & 0 \\
\hline aug-19 & 0 & 0 & 0 & 0 & 0 & 0 & 0 & 0 & 3 & 0 & 0 & 0 & 10 & 0 & 0 & 0 \\
\hline sep-19 & 0 & 0 & 0 & 0 & 0 & 0 & 0 & 0 & 7 & 0 & 0 & 0 & 14 & 4 & 0 & 0 \\
\hline oct-19 & 0 & 0 & 0 & 0 & 6 & 0 & 0 & 0 & 19 & 4 & 0 & 0 & 20 & 10 & 4 & 1 \\
\hline nov-19 & 0 & 0 & 0 & 0 & 26 & 0 & 0 & 0 & 30 & 13 & 1 & 0 & 30 & 25 & 9 & 1 \\
\hline dec-19 & 29 & 0 & 0 & 0 & 31 & 11 & 1 & 0 & 31 & 23 & 10 & 3 & 31 & 28 & 17 & 9 \\
\hline
\end{tabular}



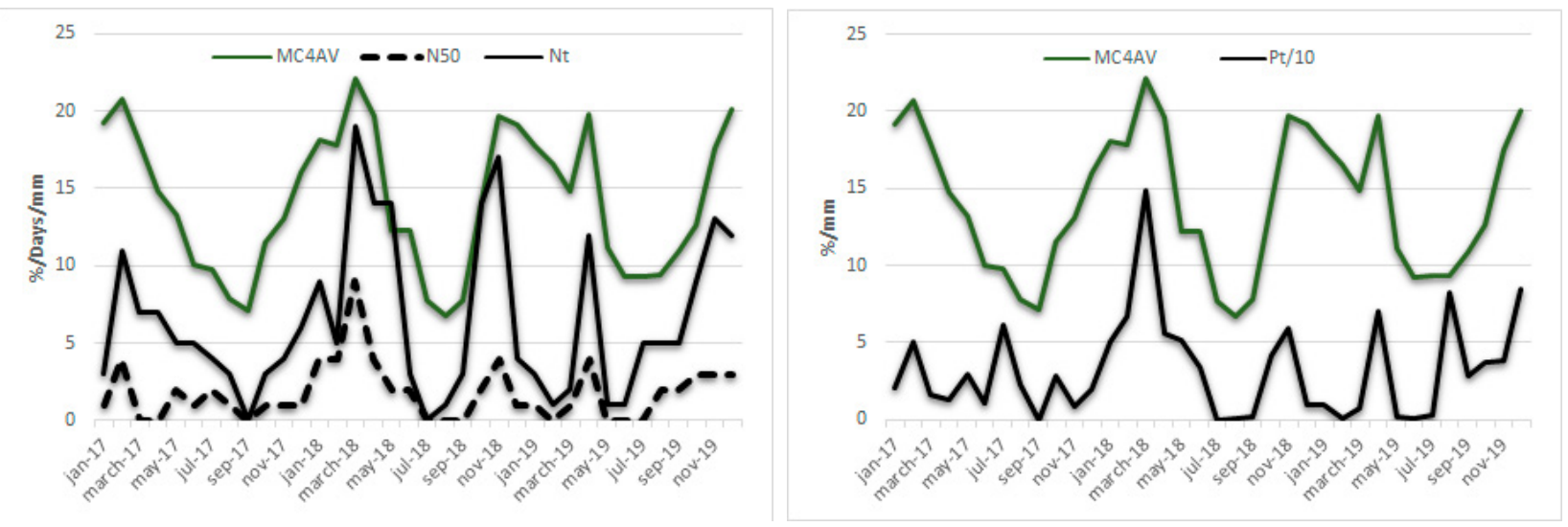

FIGURE 2. (a) Evolution over time of moisture content in \% (MC4AV), of total rainy days $\left(\mathrm{N}_{t}\right)$ and of days with more than $5 \mathrm{~mm}\left(\mathrm{~N}_{50}\right)$. (b) Evolution over time of moisture content in $\%(\mathrm{MC} 4 \mathrm{AV})$ and of total precipitation $\left(\mathrm{P}_{\mathrm{t}} / 10\right)$ in $\mathrm{mm}$.
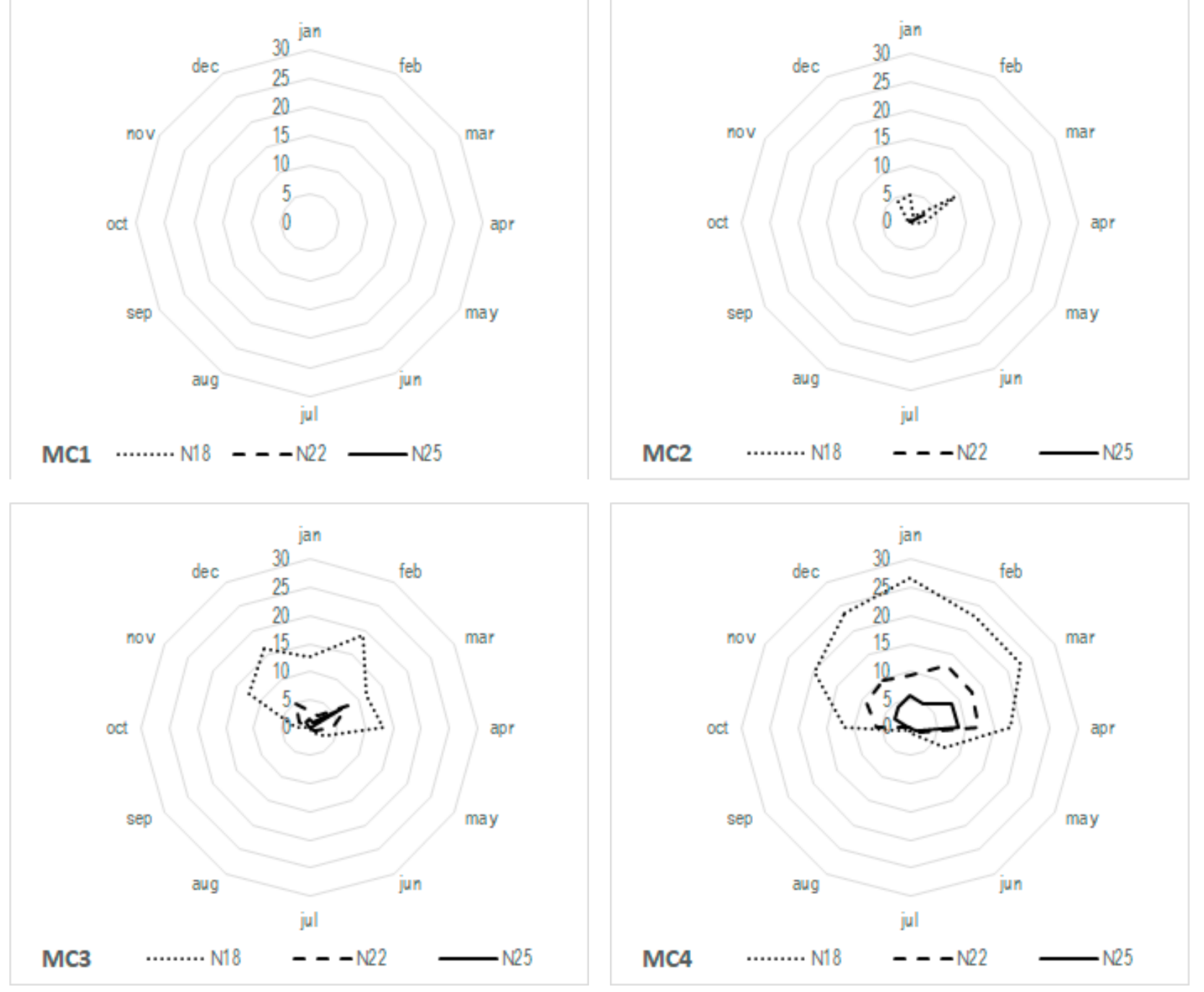

FIGURE 3. Graphical representation of the monthly average number of days with moisture content above $18 \%$ (N18), 22\% (N22) and $25 \%$ (N25) per sensor (MCX). 
TABLE 5. Differences between sensors (in \%).

\begin{tabular}{|c|c|c|c|}
\hline Month & MC2-MC1 & MC3-MC2 & MC4-MC2 \\
\hline jan-17 & 1.9 & 0.8 & 5.0 \\
\hline feb-17 & 2.4 & 1.4 & 6.7 \\
\hline mar-17 & 1.4 & 0.9 & 5.6 \\
\hline apr-17 & 1.1 & 1.4 & 4.2 \\
\hline may-17 & 0.9 & 1.6 & 4.1 \\
\hline jun-17 & 0.8 & 1.9 & 3.5 \\
\hline jul-17 & 0.9 & 2.1 & 2.6 \\
\hline aug-17 & 1.0 & 2.3 & 1.4 \\
\hline sep-17 & 0.8 & 2.1 & 1.0 \\
\hline oct-17 & 2.6 & 2.4 & 2.9 \\
\hline nov-17 & 1.5 & 1.8 & 3.7 \\
\hline dec-17 & 2.5 & 2.9 & 4.7 \\
\hline jan-18 & 2.3 & 4.3 & 7.4 \\
\hline feb-18 & 2.9 & 5.8 & 8.3 \\
\hline mar-18 & 6.4 & 4.8 & 6.8 \\
\hline apr-18 & 4.8 & 2.9 & 7.1 \\
\hline may-18 & 1.3 & 1.2 & 2.4 \\
\hline jun-18 & 1.3 & 1.2 & 2.4 \\
\hline jul-18 & 0.8 & 2.0 & 1.2 \\
\hline aug-18 & 0.5 & 2.1 & 0.8 \\
\hline sep-18 & 0.3 & 1.7 & 1.2 \\
\hline oct-18 & 1.6 & 2.4 & 6.5 \\
\hline nov-18 & 3.9 & 3.9 & 7.4 \\
\hline dec-18 & 2.6 & 3.6 & 6.3 \\
\hline jan-19 & 2.5 & 2.4 & 4.3 \\
\hline feb-19 & 1.1 & 2.9 & 5.3 \\
\hline mar-19 & 1.1 & 3.2 & 5.0 \\
\hline apr-19 & 3.9 & 4.5 & 8.2 \\
\hline may-19 & 1.0 & 2.3 & 2.1 \\
\hline jun-19 & 1.1 & 2.1 & 1.3 \\
\hline jul-19 & 1.3 & 2.3 & 2.2 \\
\hline aug-19 & 1.0 & 2.2 & 3.2 \\
\hline sep-19 & 1.9 & 2.2 & 4.0 \\
\hline oct-19 & 2.5 & 2.5 & 5.0 \\
\hline nov-19 & 3.8 & 3.2 & 6.0 \\
\hline dec-19 & 4.6 & 3.3 & 5.6 \\
\hline
\end{tabular}

TABLE 6. Individual and additive effects of the diverse variables.

\begin{tabular}{|c|c|c|c|}
\hline $\begin{array}{l}\text { Dependent } \\
\text { variables }\end{array}$ & $\begin{array}{l}\text { Independent } \\
\text { variables }\end{array}$ & $\begin{array}{l}\text { Determina- } \\
\text { tion Coef. }\end{array}$ & $\begin{array}{c}\text { Standard } \\
\text { error }\end{array}$ \\
\hline \multirow{13}{*}{ MC2-MC1 } & $\mathrm{Pt}$ & 0.526 & 0.95 \\
\hline & TAV & 0.336 & 1.13 \\
\hline & $\mathrm{Nt}$ & 0.570 & 0.92 \\
\hline & N02 & 0.047 & 1.35 \\
\hline & N10 & 0.389 & 1.08 \\
\hline & N50 & 0.664 & 0.80 \\
\hline & $\mathrm{HR}$ & 0.444 & 1.03 \\
\hline & $\mathrm{Pt}+\mathrm{TAV}$ & 0.687 & 0.77 \\
\hline & $\mathrm{Pt}+\mathrm{TAV}+\mathrm{Nt}$ & 0.716 & 0.74 \\
\hline & $\mathrm{Pt}^{*}+\mathrm{TAV}+\mathrm{N} 50$ & 0.738 & 0.72 \\
\hline & $\mathrm{Pt}^{*}+\mathrm{TAV}+\mathrm{N} 50+\mathrm{HR}$ & 0.734 & 0.71 \\
\hline & $\mathrm{TAV}+\mathrm{Nt}$ & 0.648 & 0.82 \\
\hline & TAV+N50 & 0.736 & 0.71 \\
\hline \multirow{12}{*}{ MC3·MC2 } & $\mathrm{Pt}$ & 0.240 & 0.97 \\
\hline & TAV & 0.151 & 1.03 \\
\hline & $\mathrm{Nt}^{*}$ & 0.111 & 1.05 \\
\hline & N02* & 0.000 & 1.12 \\
\hline & N10 & 0.154 & 1.11 \\
\hline & $\mathrm{N} 50$ & 0.357 & 0.89 \\
\hline & HR & 0.148 & 1.03 \\
\hline & $\mathrm{Pt}+\mathrm{TAV}$ & 0.305 & 0.93 \\
\hline & $\mathrm{Pt}+\mathrm{TAV}+\mathrm{Nt} *$ & 0.299 & 0.93 \\
\hline & $\mathrm{Pt}^{*}+\mathrm{TAV}^{*}+\mathrm{N} 50$ & 0.356 & 0.89 \\
\hline & $\mathrm{Pt}^{*}+\mathrm{TAV}^{*}+\mathrm{N} 50+\mathrm{HR}^{*}$ & 0.348 & 0.90 \\
\hline & TAV+N50 & 0.372 & 0.88 \\
\hline \multirow{12}{*}{ MC4-MC2 } & $\mathrm{Pt}$ & 0.278 & 1.88 \\
\hline & TAV & 0.620 & 1.36 \\
\hline & $\mathrm{Nt}$ & 0.420 & 1.68 \\
\hline & N02* & 0.401 & 2.17 \\
\hline & N10 & 0.312 & 1.85 \\
\hline & N50 & 0.437 & 1.66 \\
\hline & HR & 0.592 & 1.41 \\
\hline & $\mathrm{Pt}+\mathrm{TAV}$ & 0.730 & 1.15 \\
\hline & $\mathrm{Pt}^{*}+\mathrm{TAV}+\mathrm{Nt}$ & 0.756 & 1.09 \\
\hline & $\mathrm{Pt}^{*}+\mathrm{TAV}+\mathrm{N} 50$ & 0.752 & 1.10 \\
\hline & $\mathrm{Pt}^{*}+\mathrm{TAV}+\mathrm{N} 50+\mathrm{HR}^{*}$ & 0.746 & 1.12 \\
\hline & TAV+N50 & 0.759 & 1.08 \\
\hline
\end{tabular}

* non significant effect 
- Eaves (MC2-MC1) Effect of shelter from overhang of the eaves

- Distance from the ground (MC3-MC2) Effect of distance from the ground

- Horizontal-vertical arrangement (MC4-MC2) Effect of relative position (horizontal vs vertical)

An analysis was performed to determine the individual and additive effect of the different variables in order to identify correlations, taking the previously indicated differences as dependent variables, which explain the evaluated phenomena, and the recorded precipitation values as independent variables. The results are shown in Table 6 .

Finally, in Table 7 are included the monthly and annual index values and consequently the classes of use assigned to the zone of each sensor. These index values are calculated and the corresponding classes of use assigned according to the two steps procedure above mentioned and the scoring and allocation methodologies included in Tables 1 and 2. In Table 7 is also included the proposed factor (annual and overall values) to be used for evaluate each of the effects considered in the present study (eaves, distance from the ground and horizontal position).

The next section provides a detailed discussion of the results obtained for each of the studied effects.

\subsection{Effect of shelter from overhang of the eaves}

From the data contained in Table 5 it can be clearly deduced that the eaves effect (MC2-MC1) is greater in the months with the highest rainfall, especially where the greatest intensity of monthly rainfall was recorded. Table 6 includes an analysis of the additive effect of the different climatic variables on the prediction of the eaves effect, revealing a significant effect of both the temperature $\left(\mathrm{T}_{\mathrm{AV}}\right)$ and the number of days of intensive rainfall $\left(\mathrm{N}_{50}\right)$.

By comparing the effect of the three variables related to rainfall intensity $\left(\mathrm{N}_{02}, \mathrm{~N}_{10}\right.$ y $\left.\mathrm{N}_{50}\right)$ it can be observed (Table 6) that the effect increases as rainfall intensity increases. Hence, the $\mathrm{N}_{50}$ variable was selected as the most suitable for prediction purposes.

Taking these variables, the predictive model for the available data would be the following (Equation [4]):

$$
\begin{gathered}
\mathrm{MC} 2-\mathrm{MC} 1=1.96149-0.0567292 * \mathrm{~T}_{\mathrm{AV}}+ \\
0.51102 * \mathrm{~N}_{50}\left(\mathrm{R}^{2}=0.736\right)
\end{gathered}
$$

This model can be considered to provide a sufficient estimate of the phenomenon as it explains $73.6 \%$ of the observed variability.

Based on the above information, it can be concluded that the effect of the eaves is greater in situations where there are a high number of days with high intensity rainfall (between 1.0 and $5.0 \mathrm{~mm}$ ) and especially above $5.0 \mathrm{~mm}$, while a non-significant effect is associated with low intensity rainfall of between 0.2 and $1.0 \mathrm{~mm}$ (determination coefficient of $0.047 \mathrm{in} \mathrm{Ta-}$ ble 6 for the $\mathrm{N}_{02}$ variable).

If the number of days with a moisture content between 12 and 18\% (N12-N18) is analysed in Table 4, it can be seen that over three consecutive months of the year this number is very high (20-31 days/month), although in no case does this moisture content exceed the limit value of $18 \%(\mathrm{~N} 18=0)$.

According to the proposed scoring system based on the moisture content (Table 1), the index value for the $\mathrm{MC} 1$ sensor over the three years of monitoring can be seen in Table 7. The annual eaves effect factors can be calculated dividing the annual index value for MC1 by the one for MC2. The overall eaves effect factor is considered the most conservative annual value, being in this case 0.8 .

This value of 0.8 can be employed as risk reduction factor for the eaves effect $\left(k_{s l}\right.$ in expression (Equation [2]) stated in the introduction) with respect to the elements fully exposed in the vertical position (MC2).

The result obtained confirms, in terms of magnitude, the proposal in the published European technical guidelines (8-10), which establishes a value of 0.7 for the wood elements placed immediately under the eaves (at a distance less than that of the extension of the eaves, D) and 0.85 for elements situated at a distance between $\mathrm{D}$ and $2.5 \mathrm{D}$.

As the number of days with a moisture content of more than $18 \%(\mathrm{~N} 18)$ is zero, it is estimated that the risk of fungal or termite attack under these design conditions is non-existent. However, as there are a significant number of days with moisture content above $12 \%$ (N12), this design situation has to be considered to belong to use class 2 . The same assignation is produced using the annual values of the index and the allocation criteria of Table 2 .

\subsection{Effect of distance from the ground}

This design aspect was assessed by comparing the measurements from sensors MC 3 and MC2. As in the previous case, Table 6 includes an analysis of the additive effect of the different climatic variables on predicting the effect of distance from the ground, revealing a significant effect of both temperature $\left(\mathrm{T}_{\mathrm{AV}}\right)$ and the number of days with intense rainfall $\left(\mathrm{N}_{50}\right)$. The resulting predictive model is as follows (Equation [5]):

$$
\begin{gathered}
\mathrm{MC} 3-\mathrm{MC} 2=2.40276-0.0293868 * \mathrm{~T}_{\mathrm{AV}}+ \\
0.314368 * \mathrm{~N}_{50}\left(\mathrm{R}^{2}=0.372\right)
\end{gathered}
$$

Although this is the best predictive model for the observed data, it cannot be taken as valid given that, with this model, the $T_{A V}$ and $N_{50}$ alone only explain 
TABLE 7. Calculation of annual index values and effect factors.

\begin{tabular}{|c|c|c|c|c|c|c|c|c|}
\hline Month & MC1AV (\%) & Value & MC2AV (\%) & Value & MC3AV (\%) & Value & MC4AV (\%) & Value \\
\hline jan-17 & 14.4 & 2.5 & 16.3 & 2.7 & 17.1 & 2.7 & 21.3 & 3.2 \\
\hline feb-17 & 14.9 & 2.5 & 17.3 & 2.7 & 18.7 & 3.0 & 23.9 & 3.5 \\
\hline mar-17 & 13.4 & 2.0 & 14.7 & 2.5 & 15.7 & 2.5 & 20.3 & 3.2 \\
\hline apr-17 & 11.1 & 1.0 & 12.2 & 2.0 & 13.6 & 2.0 & 16.4 & 2.7 \\
\hline may-17 & 9.9 & 0.9 & 10.8 & 1.0 & 12.4 & 1.0 & 14.9 & 2.5 \\
\hline jun-17 & 7.9 & 0.7 & 8.7 & 0.8 & 10.6 & 1.0 & 12.2 & 2.0 \\
\hline jul-17 & 7.7 & 0.7 & 8.5 & 0.8 & 10.7 & 1.0 & 11.1 & 1.0 \\
\hline aug-17 & 6.7 & 0.7 & 7.6 & 0.7 & 10.0 & 1.0 & 9.0 & 0.9 \\
\hline sep-17 & 7.0 & 0.7 & 7.8 & 0.7 & 9.9 & 0.9 & 8.8 & 0.8 \\
\hline oct-17 & 7.8 & 0.7 & 10.4 & 1.0 & 12.9 & 2.0 & 13.4 & 2.0 \\
\hline nov-17 & 9.7 & 0.9 & 11.2 & 1.0 & 13.0 & 2.0 & 14.9 & 2.5 \\
\hline dec-17 & 11.1 & 1.0 & 13.6 & 2.0 & 16.4 & 2.7 & 18.3 & 3.0 \\
\hline Annual Index value & & 1.2 & & 1.5 & & 1.8 & & 2.3 \\
\hline Use Class & $\mathrm{UC2}$ & & UC3.1 & & UC3.2 & & UC3.2 & \\
\hline Annual Effect factor & 0.8 & & 0.7 & & 1.2 & & & \\
\hline jan-18 & 13.2 & 2.0 & 15.5 & 2.5 & 19.8 & 3.0 & 22.9 & 3.5 \\
\hline feb-18 & 13.0 & 2.0 & 15.1 & 2.5 & 20.6 & 3.2 & 22.7 & 3.5 \\
\hline mar-18 & 14.0 & 2.5 & 20.5 & 3.2 & 25.2 & 3.5 & 27.3 & 4.0 \\
\hline apr-18 & 11.0 & 1.0 & 15.9 & 2.5 & 18.8 & 3.0 & 23.0 & 3.5 \\
\hline may-18 & 9.6 & 0.9 & 10.9 & 1.0 & 12.1 & 2.0 & 13.2 & 2.0 \\
\hline jun-18 & 9.6 & 0.9 & 10.9 & 1.0 & 12.1 & 2.0 & 13.2 & 2.0 \\
\hline jul-18 & 6.7 & 0.7 & 7.5 & 0.7 & 9.5 & 0.9 & 8.7 & 0.8 \\
\hline aug-18 & 6.6 & 0.7 & 7.1 & 0.7 & 9.2 & 0.9 & 7.8 & 0.7 \\
\hline sep-18 & 7.1 & 0.7 & 7.3 & 0.7 & 9.0 & 0.9 & 8.6 & 0.8 \\
\hline oct-18 & 9.3 & 0.9 & 10.8 & 1.0 & 13.3 & 2.0 & 17.3 & 2.7 \\
\hline nov-18 & 11.5 & 1.0 & 15.4 & 2.5 & 19.3 & 3.0 & 22.8 & 3.5 \\
\hline dec-18 & 12.1 & 2.0 & 14.7 & 2.5 & 18.3 & 3.0 & 21.0 & 3.2 \\
\hline Annual Index value & & 1.3 & & 1.7 & & 2.3 & & 2.5 \\
\hline Use Class & $\mathrm{UC2}$ & & UC3.1 & & UC3.2 & & UC3.2 & \\
\hline Annual Effect factor & 0.7 & & 0.7 & & 1.3 & & & \\
\hline jan-19 & 12.7 & 2.0 & 15.2 & 2.5 & 17.6 & 2.7 & 19.6 & 3.0 \\
\hline feb-19 & 12.3 & 2.0 & 13.4 & 2.0 & 16.4 & 2.7 & 18.7 & 3.0 \\
\hline mar-19 & 10.7 & 1.0 & 11.9 & 1.0 & 15.1 & 2.5 & 16.8 & 2.7 \\
\hline apr-19 & 10.9 & 1.0 & 14.8 & 2.5 & 19.3 & 3.0 & 22.9 & 3.5 \\
\hline may-19 & 8.9 & 0.8 & 9.9 & 0.9 & 12.2 & 2.0 & 12.0 & 2.0 \\
\hline jun-19 & 7.3 & 0.7 & 8.4 & 0.8 & 10.5 & 1.0 & 9.7 & 0.9 \\
\hline jul-19 & 7.0 & 0.7 & 8.3 & 0.8 & 10.7 & 1.0 & 10.5 & 1.0 \\
\hline aug-19 & 6.5 & 0.7 & 7.5 & 0.7 & 9.7 & 0.9 & 10.8 & 1.0 \\
\hline sep-19 & 6.8 & 0.7 & 8.7 & 0.8 & 10.9 & 1.0 & 12.7 & 2.0 \\
\hline oct-19 & 7.8 & 0.7 & 10.4 & 1.0 & 12.9 & 2.0 & 15.4 & 2.5 \\
\hline nov-19 & 10.3 & 1.0 & 14.1 & 2.5 & 17.3 & 2.7 & 20.1 & 3.2 \\
\hline dec-19 & 12.5 & 2.0 & 17.0 & 2.7 & 20.4 & 3.2 & 22.7 & 3.5 \\
\hline Annual Index value & & 1.1 & & 1.5 & & 2.1 & & 2.4 \\
\hline Use Class & $\mathrm{UC2}$ & 2.2 & UC3.1 & 3.0 & UC3.2 & 4.1 & UC3.2 & 4.7 \\
\hline Annual Effect factor & 0.7 & & 0.6 & & 1.4 & & & \\
\hline Overalll Index value & & 1.3 & & 1.7 & & 2.3 & & 2.5 \\
\hline Use Class & UC2 & & UC3.1 & & UC3.2 & & UC3.2 & \\
\hline Overall Effect factor & 0.8 & & 0.7 & & 1.4 & & & \\
\hline Effect & Eave & & $\mathrm{V} / \mathrm{Hz}$ & & Ground & & & \\
\hline Factor & 0.8 & & 0.7 & & 1.4 & & & \\
\hline
\end{tabular}


$37.2 \%$ of the variability. This low coefficient of determination is not surprising since the difference between MC3-MC2 depends on more than strictly climatic variables. Among other factors, the effect of soil moisture (not measured) influences the capillary ascent of the water through the pillars.

If the number of days with moisture content between $12 \%$ and $18 \%(\mathrm{~N} 12-\mathrm{N} 18)$ for sensor 3 are analysed in Table 4, it can be observed that for every month of the year, except those with a very low number of days of rainfall, the results are high. If the number of days with moisture content of between 18 and 22\% (N18-N22) are analysed, it can be seen that when the number of days in the month with high rainfall $\left(\mathrm{N}_{50}\right)$ is high, the value is still relatively high. However, since the number of days with moisture content above $25 \%$ (N25) is zero or very low throughout the year, it can be concluded that the risk of decay is moderate-high. According to the annual values of the index, an assignation of class of use of 3.2 should be used for the zone corresponding to sensor 3 .

In accordance with the proposed scoring system based on the moisture content (Table 1), the index value for the MC3 over the monitoring period of three years can be seen in Table 7 (2.3). The annual factors for the effect of distance to the ground can be calculated dividing the annual index value for MC3 by the one for MC2. The overall value for the distance to the ground effect is considered the most conservative annual value, being in this case was 1.4.

This latter value of 1.4 reveals that the distance from the ground or damp walls is an important and aggravating factor to be taken into account in order to mitigate the risk of decay.

The value of 1.4 is much lower than the proposal present in the European technical guidelines (8-10), which establishes a value of 1.5 for distances from the ground of $100-300 \mathrm{~mm}$ and of 2.0 for distances $<100 \mathrm{~mm}$. In our study, the value is 1.4 , probably because rainfall, and probably soil moisture, is much lower in Madrid than that at the central and northern European sites where the factor of 2.0 was established. For this reason, it is worth noting the great effect that climatic conditions have on the value of this factor and the need to carry out additional research to model its value in relation with the local climate. However, we have to draw attention to the fact that the value proposed by the mentioned European technical guides refers to pillars that are not in direct contact with the ground, which is not our case.

According to the data, a value of the modification factor of the basic index for distance to the ground 1.4 can be used, in the climate of Madrid, for the part of the pillars in contact with the ground, at least up to $200 \mathrm{~mm}$ from the ground. For the part embedded in the ground or in wet walls, a use class assignment of 4 should still apply.

In any case, it is advisable to separate, at least 200 $\mathrm{mm}$, the timber members from the ground, founda- tions or using barriers to humidity from wet walls, adopting the necessary architectural measures. If this solution is not possible, an aggravating factor coefficient of 1.4 should be adopted.

\subsection{Effect of relative position (horizontal vs vertical)}

This design condition was analysed by comparing the readings from sensors MC4 and MC2. Table 6 includes an analysis of the additive effect of the different climatic variables on predicting the effect of the relative position of the element, revealing a significant effect of temperature $\left(\mathrm{T}_{\mathrm{AV}}\right)$. The best prediction is obtained by using the $\mathrm{T}_{\mathrm{AV}}$ and $\mathrm{N}_{50}$ together in the following expression (Equation [6]) (5):

$$
\begin{gathered}
\mathrm{MC} 4-\mathrm{MC} 2=6.26213-0.183079 * \mathrm{~T}_{\mathrm{AV}}+ \\
0.487984 * \mathrm{~N}_{50}\left(\mathrm{R}^{2}=0.795\right)
\end{gathered}
$$

The estimate is sufficiently precise since these two variables alone explain $79.5 \%$ of the variability.

In Table 4, if we analyse the number of days with moisture content between 12 and 18\% (N12-N18), corresponding to sensor MC4, it can be observed that for all the months of the year, with the exception of those with a very low number of days of rainfall (May to September), the values are high. It can also be observed that the number of days with moisture content above $18 \%$ (N18), above $22 \%$ (N22) and even above $25 \%$ (N25) are significantly high for the months with high rainfall (January, February, March, April and December). The fact that the moisture content in the summer months (July, August and September) falls below 9\% (Table 3 ), leading to complete drying of wood elements, explains that degradation due to fungi was undetectable four years after installing the experiment, although the risk cannot be considered non-existent. According to the annual values of the index and the allocation criteria of T, an assignation of class of use of 3.2 should be used.

In accordance with the proposed scoring system based on the moisture content (Table 1), the index value for the MC4 sensor over the three years of monitoring can be seen in Table 7 (2.5). The annual position effect factors can be calculated dividing the annual index value for MC2 by the one for MC4. The overall positional effect factor is considered the most conservative annual value, being in this case 0.7 (vertical vs horizontal). According to this, the risk of attack by fungi in elements placed in the vertical position (under the climatological conditions of Madrid) are $30 \%$ lower than for elements placed in the horizontal position. As far as the assignation of classes of use is concerned and taking into consideration the allocation criteria of Table 2 , the class of use corresponding to the sensor 2 (vertical position out of contact to ground) in Madrid is 3.1 and the one corresponding to the horizontal position is 3.2 . 
Comparing this result with the one of 0.9 proposed by the European technical guidelines (8-10), for the timber elements placed vertically out of contact to the ground and with sufficient ventilation on all their four sides, our value of 0.7 is perfectly possible due to the notably lower rainfall in Madrid compared to the Northern European sites on which the north-European studies were based. This result confirms, once again, that it would be necessary to carry out further research to model the value of this factor in relation with the local climate.

\section{CONCLUSIONS}

According to the data obtained, the following conclusions can be drawn:

1. The variables that best explain the annual evolution of the moisture content at the different points on the experimental set-up are air temperature $\left(\mathrm{T}_{\mathrm{AV}}\right)$ and precipitation above $5.0 \mathrm{~mm}\left(\mathrm{~N}_{50}\right)$.

2. The existence of a significant real effect on wood moisture content as a consequence of certain design aspects such as protective eaves, distance from the ground and relative position of the elements (vertical vs horizontal) has been verified.

3 . The sheltering effect from eaves has been quantified by a reducing factor $\left(\underline{k}_{s i}\right)$ of 0.8 with respect to the elements fully exposed in the vertical position. The result obtained agrees with that published in some European technical guidelines (8-10).

4. The effect of the distance from the ground has also been stated. According to the data, an aggravating factor of the basic index for the distance to the ground of 1.4 can be used, in the climate of Madrid, for the part of the pillars in contact with the ground, at least up to $200 \mathrm{~mm}$ from the ground. For the part embedded in the ground or in wet walls, a use class assignment of 4 should anyhow applied. This value of 1.4 is much lower than that reflected by the bibliography (8-10) for elements located at a distance $<100 \mathrm{~mm}$ from the ground probably due to the characteristics of the climate in Madrid (drier and hotter). More research will be necessary to assess the variation of this factor with the distance to the ground and with the characteristics of the local climate.

5. Horizontal positioning of elements inevitably leads to greater moisture content than that of vertically positioned elements. Considering that the basic exposure index $\left(I_{s 0}\right)$ value is obtain for an element placed horizontally a reducing factor $\left(\underline{k}_{s i}\right)$ of 0.7 can be used for elements placed vertically. This difference in behaviour means that the use class assignment in many geographical locations may vary for external-use wood elements depending on whether they are positioned vertically or horizontally.
6. The correction factors obtained in this study differ to a certain extent from those in the bibliography (8-10), which were obtained at geographical locations with very different climates to that of Madrid (Spain), highlighting the need to carry out more research in locations with different climates.

7. In future studies it would be advisable to monitor moisture content of the wooden pillars at distances of $10 \mathrm{~mm}, 100 \mathrm{~mm}, 200 \mathrm{~mm}$ and 300 $\mathrm{mm}$ from the ground to determine the real effect of separation from the ground, not only in members in direct contact with the soil but also in members separated from the ground by means of air gaps or barriers to humidity.

8. Similarly, future studies should analyse different building support solutions for transversal joining of elements, etc. as a means to assess their influence on monthly moisture content evaluation.

\section{ACKNOWLEDGEMENTS}

This work was carried out in the Wood Technology Laboratories of the CIFOR-INIA and the University of Cordoba, with financial support by the Spanish National Plan under Grant BIA2013-42434-R and the Operational Group "Wood Sustainable Construction" of the European Association for Innovation in Agricultural Productivity and Sustainability (AEI-AGRI).

\section{REFERENCES}

1. Brischke, C.; Jones, D. (2016) Performance of bio-based building products - Recent activities within COST Action FP 1303, Holztechnologie. 57 [2], 47-54.

2. Brischke, C.; Bayerbach, R.; Rapp, A.O. (2007) Decay influencing factors: a basis for service life prediction of wood and wood-based products. Wood Mat. Sci. Eng. 1, 91-107. https:// doi.org/10.1080/17480270601019658.

3. Brischke, C.; Soetbeer, A.; Meyer-Veltrup, L. (2017) The minimum moisture threshold for wood decay by basidiomycetes revisited. A review and modified pile experiments with Norway spruce and European beech decayed by Coniophora puteana and Trametes versicolor. Holzforschung. 71 [11], 893-903. https://doi.org/10.1515/hf-2017-0051.

4. Morris, P.; Winandy, J.E. (2002) Limiting conditions for decay in wood systems. International Research Group on Wood Protection, Stockholm, IRG/WP 02-10421.

5. Isaksson, T.; Thelandersson, S. (2013) Experimental investigation on the effect of detail design on wood moisture content in outdoor above ground applications. Build. Environ. 59, 239-249. https://doi.org/10.1016/j.buildenv.2012.08.023.

6. Meyer-Veltrup, L.; Brischke, C. (2017) Design and performance prediction of timber structures based on a factorization approach. International Research Group on Wood Protection, Stockholm,IRG/WP 17-20603. IRG, Stockholm.

7. Brischke, C.; Thelandersson, S. (2014) Modelling the outdoor performance of wood products - A review on existing approaches. Const. Buil. Mater. 66, 384-397. https://doi. org/10.1016/j.conbuildmat.2014.05.087.

8. Thelandersson, S.; Isaksson, T.; Suttie, E.; Frühwald, E.; Toratti, T.; Grüll, G.; Viitanen, H.; Jermer, J. (2011) Service life of wood in outdoor above ground applications: Engineering design guideline. Background document. Rapport TVBK-3061, ISSN 0349-4969. Lund University, Sweden. 
9. Isaksson, T.; Thelandersson, S.; Jermer, J.; Brischke, C. (2015) Service life of wood in outdoor above ground applications: Engineering design guideline. Background document Rapport TVBK-3067. Lund University, Division of Structural Engineering, Lund, Sweden. ISBN 978-87993-02-2

10. Jermer, J. (Editor); Thelandersson, S.; Viitanen, H.; Toratti, T.; Grüll, G.; Steitz, A.; Michael, T.; Bader, T.; Alfredsen, G.; Suttie, E.; De Windt, I.; Van Acker, J.; Bollmus, S.; Podgorski, L. (2011) WoodExter-Service life and performance of exterior wood above ground. Final SP Report 2011: 53 pp.

11. UNE-EN 252:2015 Field test method for determining the relative protective effectiveness of a wood preservative in ground contact. AENOR, Asociación Española de Normalización (in Spanish).

12. ISO 15686-1 (2011) Buildings and constructed assets - Service life planning - Part 1: General principles and framework. International Organization for Standardization, Genève.

13. Marteinsson, B. (2003) Durability and the factor method of ISO 15686-1. Build. Res. Inf. 31 [6], 416-426. https://doi.org $/ 10.1080 / 0961321032000105412$.

14. Fernandez-Golfin, J.; Larrumbide, E.; Ruano, A.; Galvan, J.; Conde, M. (2016) Wood decay hazard in Spain using the Scheffer index: proposal for an improvement. Eur. Wood Wood Prod. 74, 591-599. https://doi.org/10.1007/s00107016-1036-z.

15. Viitanen, H.; Toratti, T.; Peuhkuri, R.; Ojanen, T.; Makkonen, L. (2009) Evaluation of exposure conditions for wooden facades and decking. . International Research Group on Wood Protection, Stockholm, IRG/WP 09-20408.

16. Bornemann, T.; Brischke, C.; Lück, J.M. (2012) Comparative studies on the moisture performance and durability of wooden facades. Proceedings IRG annual meeting 2012. International Research Group on Wood Protection, Stockholm, IRG/WP 12-20492.

17. Humar, M.; Kržišnik, D.; Lesar, B.; Brischke, C. (2019) The performance of wood decking after five years of exposure: verification of the combined effect of wetting ability and durability. Forests. 10 [10], 903-920. https://doi.org/10.3390/f10100903.

18. Niklewski, J.; Brischke, C.; Frühwald Hansson, E. (2021) Numerical study on the effects of macro climate and detailing on the relative decay hazard of Norway spruce. Wood Mater. Sci. Eng. 16 [1], 12-20. https://doi.org/10.1080/17480272.2019.1608296.

19. Kutnik, M.; Montibus, M. (2019) Durability by design - a case study of the performance of wooden decks after 9.5 years of natural weathering. International Research Group on Wood Protection, Stockholm, IRG/WP 19-20648.

20. Niklewski, J.; Fredriksson, M. (2021) The effects of joints on the moisture behaviour of rain exposed wood: a numerical study with experimental validation. Wood Mater. Sci. Eng. 16 [1], 1-11. https://doi.org/10.1080/17480272.2019.1600163.

21. Isaksson, T.; Thelandersson, S. (2013) Experimental investigation on the effect of detail design on wood mois- ture content in outdoor above ground applications. Build. Environ. 59, 239-249. https://doi.org/10.1016/j.buildenv.2012.08.023

22. Brischke, C.; Frühwald Hansson, E.; Kavurmaci, D.; Thelandersson, S. (2011) Decay hazard mapping for Europe. IRG/WP 11-20463. IRG, Stockholm.

23. Fruhwald Hansson, E.; Brischke, C.; Meyer, L.; Isaksson, T.; Thelandersson, S.; Kavurmaci, D. (2012) Durability of timber outdoor structures. Modelling performance and climatics impacts. In: World Conference on Timber Engineering. Auckland. 16-19.

24. Tajet, H.T.T.; Hygen, H.O. (2017) Potential risk of wood decay. MET report no. 8/2017 ISSN 2387-4201 Division for Climate Services. Norwegian Meteorological Institute.

25. Scheffer, T.C. (1971) A climate index for estimating potential for decay in wood structures above ground. Forest Prod. J. 21 [10], 25-31

26. Fernández-Golfín Seco, J.I.; Peraza Sánchez, F.; Touza Vázquez, M.; Arriaga Martitegui, F. (2018) Guía para la asignación de clases de uso y de servicio a los productos de la madera. Monografía INIA Serie Forestal $n^{\circ} 30$. España. Madrid. 95 pp. (in Spanish).

27. UNE EN 335:2013. Durability of wood and wood-based products - Use classes: definitions, application to solid wood and wood-based products (Spanish version). European Committee of Standardization (Spanish version).

28. PNE-prEN 460: 2020. Durability of wood and wood-based products - Natural durability of solid wood - Guide to the durability requirements for wood to be used in hazard classes.

29. Suttie, E.; Brischke, C.; Meyer, L.; Van Acker, J.; Kutnik M.; Heisel, E.; Englund, F.; Jermer, J.; Thelandersson, S.; Polášek, M.; Lorenzo, D. (2014) Performance classification of wood in construction - drafting a user-friendly European standard. International Research Group on Wood Protection, Stockholm, IRG/WP 14-20545.

30. Kutnik, M.; Suttie, E.; Brischke, C. (2014) European standards on durability and performance of wood and wood-based products - Trends and challenges. Wood Mater. Sci. Eng. 9 [3], 122-133. https://doi.org/10.1080/17480272.2014.894574.

31. Ministerio de Fomento (2009). Documento básico SE-M Seguridad estructural madera. Código Técnico de la Edificación (in Spanish).

32. Conde Garcia, M.; Conde García, M.; Fernández-Golfín, J.I. (2021) Improving the accuracy of wood moisture content estimation in four European softwoods from Spain. Forest Systems, 30 [1], e002. https://doi.org/10.5424// fs/2021301-17798.

33. Conde García, M.; Conde García, M.; Fernández-Golfín, J.I. (2021) Species effect on decay resistance of wood exposed to exterior conditions above the ground in Spain. Mater. Construcc. 71 [341], e236. https://doi.org/10.3989/ mc. 2021.11320 . 